\title{
Employment and Gender Issues in National Development
}

\author{
Dewi Rohma Wati \\ Department of Agribusiness
Faculty of Science and Technology State Islamic University \\ Jakarta, Indonesia \\ Email: dewi.rohma.wati@uinjkt.ac.id
}

\begin{abstract}
Economic growth involves not only natural resources and capital resources. The growth of a country's economy can be achieved because of the active participation of both men and women. The purpose of this study is to examine gender and employment issues in national development. The importance of engaging gender issues in development programs in Indonesia was not only done and felt by the male population, but also women. Based on data that have been analyzed descriptively, shows that labor in Indonesia is still dominated by men although the difference is relatively small. This is because the women are still low educated so the opportunity to get a job was reduced and eventually unemployed. Therefore, it is necessary to review the policy regarding labor and to do a special approach to make it balance.
\end{abstract}

Keywords: Gender, Economic development, Women, Labor

\section{Introduction}

Development is an effort of a nation to change conditions that are less good to be better (Tjaja, 2000). Economically, such an action is called economic transformation in which the orientation of the agricultural sector is reduced by developing a non-agricultural sector or so-called industrialization (Norton, 2010). The occurrence of industrialization in all sectors of the economy encourages the creation of employment for all skilled and educated human resources. Sectoral transformation promotes better economic growth and allows all communities to play an active role in developing the economy. The economic growth of a country can be seen from the increase in the gross domestic product (GDP), which is the result of natural and human resources utilization provided (Dornbusch et al, 2008). Table 1 presents data on Indonesia's GDP over the past few years. Indonesia's economic growth in 2013 declined slightly but in quantity is still higher than in 2012. This is due to the increase in population which resulted in lower per capita income, although relatively small.

Successful development in Indonesia is the result of the participation of all communities, both men and women, as agents and beneficiaries of development outcomes. Specifically, qualified women will have a positive impact on two things: (1) women can become active partners in dealing with social, economic and political issues because the approach is the dominance between logic and emotional; (2) qualified women will give birth to a quality generation as well as to provide good education for their children (Ministry of Women Empowerment and Child Protection, 2013).

Table 1 GDP Among Economic Sectors Year 2007 - 2013

\begin{tabular}{|c|c|c|c|c|c|c|c|c|}
\hline \multirow{2}{*}{ No } & \multirow{2}{*}{ Information } & \multicolumn{7}{|l|}{ Year } \\
\hline & & 2007 & 2008 & 2009 & 2010 & 2011 & 2012 & 2013 \\
\hline 1 & $\begin{array}{l}\text { GDP (USD } \\
\text { Billion) }\end{array}$ & 364.9 & 432.1 & 510.2 & 539.4 & 706.6 & 846.8 & 878.0 \\
\hline 2 & $\begin{array}{l}\text { GDP per } \\
\text { capita (USD) }\end{array}$ & 1.923 & 2.244 & 2.345 & 2.984 & 3.467 & 3,546 & 3.468 \\
\hline 3 & $\begin{array}{l}\text { Growth Rate } \\
\text { of GDP }\end{array}$ & 6.3 & 6.1 & 4.6 & 6.1 & 6.5 & 6.2 & 5.8 \\
\hline
\end{tabular}

Source: Indonesia Investments (2015)

The Government of Indonesia has implemented the necessary efforts to foster equitable and gender-inclusive development (Randy, 2011). This is done in order to implement Presidential Instruction No. 3 of 2010 that development in Indonesia must have a fair value. Crosssectorally, it should be ensured that men and women, boys and girls, all have equal access and opportunity to development processes and results in the country. Of the 173 countries in the world, Indonesia is a tolerant country and provides opportunities for women to grow and work just like men (Chand, 2015).

The 2010 census noted that Indonesia's population is $237,641,326$ people with a growth rate of 1.49 percent (BPS, 2011). The number of male population as much $119,630,913$ inhabitants and the population of women as much as 118,010,413 inhabitants. As for the amount, about 118.19 million people are the population with productive age (included in the labor force). The latest data recorded in BPS indicates that in 2013 between the number of job seekers and available employment was unbalanced, so there is still unemployment around 6.15 percent (BPS, 2015). This is closely related to the quality of education and also the policy in obtaining education. The quality of good education will improve the quality of human resources in the competition of work and business (Fitri, 2012). 
The achievements of human development based on the basic components of quality of life are measured in 3 dimensions, which are long-lived and healthy, have knowledge, and have a decent life. As in other countries, these achievements are measured in a Human Development Index (HDI). At the ASEAN level, Indonesia ranks 6th in HDI measurement results, which is 0.629 in 2012 (Ministry of Women Empowerment and Child Protection, 2013). This indicates there is still a lot of work for the government to increase the value of HDI nationally if you want to compete with other countries.

While to see the extent of gender equality in national development, it is measured by an index of gender imbalances that indicate a loss in human development resulting from a gender gap. Based on the human development report of 2013, the gender inequality index in Indonesia is still above 0.5 . This means there are still many inequalities experienced by Indonesian women in enjoying decent living, education, and health.

From all backgrounds, the roles of men and women should be important for review based on existing data specifically from the education and employment aspect.Therefore, a description based on existing data and facts that development in Indonesia is already directed to gender equality and have equal opportunity in enjoying the results of development.

\section{Gender Perspective in Economy}

Differences and functions of social roles constructed by society and related to responsibilities between men and women are gender. Gender deals with the process of beliefs about how men and women act in accordance with the structured values, local social and cultural requirements (Saifuddin, 1997).

Humans are born as men and women, but humans learn to be masculine or feminine (Laswell and Laswell; Kamanto 2000; Lestari 2014). In any country, Sanderson in Lestari (2014) says every community group uses sex as the main criterion in dividing work for individuals. The different roles of men and women naturally make the work for men and women different. This raises the gender (biological) and social (gender) perspectives shown in Table 3 below:

Table 2 Differences in Characteristics of Sex and Gender

\begin{tabular}{|c|c|c|}
\hline Characteristics & Sex & Gender \\
\hline Distinct source & God & Human \\
\hline Distinct element & $\begin{array}{l}\text { Biological (reproductive } \\
\text { organs) }\end{array}$ & Culture (behavior) \\
\hline Character & $\begin{array}{l}\text { Certain natures, not } \\
\text { interchangeable }\end{array}$ & $\begin{array}{l}\text { On behalf of dignity and } \\
\text { dignity, it can be exchanged }\end{array}$ \\
\hline Impact & $\begin{array}{l}\text { The creation of } \\
\text { complementary values of } \\
\text { perfection, thus benefiting } \\
\text { both parties }\end{array}$ & $\begin{array}{l}\text { The creation of norms / } \\
\text { provisions on "inappropriate / } \\
\text { inappropriate", so often harm } \\
\text { one party, especially women }\end{array}$ \\
\hline Enforceability & $\begin{array}{l}\text { Throughout time, anywhere, } \\
\text { do not recognize class / } \\
\text { tribal differences }\end{array}$ & $\begin{array}{l}\text { Can change, seasonal, and } \\
\text { different between classes / } \\
\text { tribes }\end{array}$ \\
\hline
\end{tabular}

Source: Handayani 2005 in Lestari 2014
Because gender is not something absolute, its validity can change according to the times and policies adopted by the government. Presidential Instruction No. 3 of 2010 on Fair Development Program clearly aims to ensure that all Indonesian citizens have equal rights in enjoying and participating in the development itself such as education and decent living. However, inequality still occurs, one of them in obtaining education which can be seen in Table 3 .

Table 3 Total Population of Men and Women Age 15 Years and over by Education Level pursued (in percent)

\begin{tabular}{|c|c|c|c|c|c|c|c|c|c|c|}
\hline \multirow{2}{*}{$\begin{array}{l}\text { Educationa } \\
\text { level }\end{array}$} & \multicolumn{2}{|l|}{$1^{2009}$} & \multicolumn{2}{|l|}{2010} & \multicolumn{2}{|l|}{2011} & \multicolumn{2}{|l|}{2012} & \multicolumn{2}{|l|}{2013} \\
\hline & $\mathrm{Lk}$ & $\operatorname{Pr}$ & Lk & $\operatorname{Pr}$ & Lk & $\operatorname{Pr}$ & Lk & $\operatorname{Pr}$ & Lk & $\operatorname{Pr}$ \\
\hline $\begin{array}{l}\text { No school } \\
\text { ever }\end{array}$ & 4.29 & 10.54 & 4.38 & 10.12 & 3.76 & 9.02 & 3.45 & 8.30 & 3.36 & 8.15 \\
\hline $\begin{array}{l}\text { Has not } \\
\text { finished } \\
\text { primary } \\
\text { school }\end{array}$ & 1 & 15.59 & 12.06 & 13.40 & 13.82 & 15.55 & 13.01 & 14.79 & 13.13 & 315.14 \\
\hline $\mathrm{SD} /$ equal & 29.37 & 29.25 & 29.82 & 29.63 & 28.91 & 28.52 & 27.92 & 28.26 & 28.19 & 28.18 \\
\hline $\begin{array}{l}\text { SMP / } \\
\text { equal }\end{array}$ & 20.61 & 19,12 & 21.21 & 19.94 & 21.23 & 20.25 & 21.31 & 20.63 & 21.00 & 20.20 \\
\hline $\begin{array}{l}\text { SMA / } \\
\text { equal }\end{array}$ & 24.96 & 19.37 & 25.41 & 20.29 & 25.50 & 19.97 & 26.93 & 21.02 & 24.47 & 721.57 \\
\hline College & 6.67 & 6.13 & 7.12 & 6.62 & 6.79 & 6.67 & 7.37 & 6.96 & 6.86 & 6.94 \\
\hline
\end{tabular}

Source: BPS, 2015

Towards the era of ASEAN regional free trade that falls on January 1, 2016, one way to compete is through education, especially formal education. The number of Indonesian citizens who have never attended school is still relatively high, reaching 11.51 percent (3.36 percent male and 8.15 percent female) of the total population of Indonesia in 2013. The number of Indonesian citizens who do not / This school has never been dominated by women mainly because of living in rural areas. Education priorities in rural areas are still reserved for men because they are deemed to have the ability to find decent jobs to support their families. While women are still considered will only act as housewives.

Todaro and Smith (2006) in Harahap (2014) explain empirically why women are entitled to a proper education like men. Some of these reasons are related to the return of educational capital, higher work productivity, more controlled birth rates for not getting married at a very young age, and giving birth to smarter children because of being cared for by an educated mother. That way, there is really no reason for women to not be able to enjoy education just because women are not leaders or do not deserve to be leaders.

\section{Employment in Gender Perspectiv}

Labor is a human resource that is directly related to the development of a country. Direct economic drivers as producers as well as consumers. Both as producers and consumers must have the knowledge and education of what is consumed and produced. Such knowledge is gained from both formal and informal education. The mandate of the 1945 Constitution guarantees that Indonesians are entitled to basic education without discriminating sex so that it opens opportunities for employment. The gap in obtaining education may 
ultimately have an impact on employment opportunities for men and women who are also inequalized. The government through BPS in the national labor survey noted that between job seekers and employment the number is unbalanced resulting in unemployment. Table 4 presents the number of labor force, employment rate, and unemployment that occurred in Indonesia during 2006 to 2013.

Table 4 Employment Conditions in Indonesia 2006 - 2013

\begin{tabular}{cccccc}
\hline Year & $\begin{array}{c}\text { Labor } \\
\text { Force } \\
\text { (Million) }\end{array}$ & $\begin{array}{c}\text { Working } \\
\text { (Million) }\end{array}$ & $\begin{array}{c}\text { Unem- } \\
\text { ployment } \\
\text { (Million) }\end{array}$ & $\begin{array}{c}\text { Labor Force } \\
\text { Participa- } \\
\text { tion Rate - } \\
\text { LFPR (\%) }\end{array}$ & $\begin{array}{c}\text { Unemploy- } \\
\text { ment Rate - } \\
\text { TPT (\%) }\end{array}$ \\
\hline 2006 & 106.39 & 95.46 & 10.93 & 66.16 & 10.28 \\
2007 & 109.94 & 99.93 & 10.01 & 66.99 & 9.11 \\
2008 & 111.95 & 102.55 & 9.39 & 67.18 & 8.39 \\
2009 & 113.83 & 104.87 & 8.96 & 67,23 & 7.87 \\
2010 & 116.53 & 108.21 & 8.32 & 67,72 & 7.14 \\
2011 & 117.37 & 109.67 & 7.70 & 68.34 & 6.56 \\
2012 & 118.05 & 110.81 & 7.24 & 67.88 & 6.14 \\
2013 & 118.19 & 110.80 & 7.39 & 66.90 & 6.25 \\
\hline
\end{tabular}

Source: BPS, 2015

Based on Table 4 above, it can be seen that the work force in question is a population aged 15 years and over. The number of the workforce continues to grow as the population increases. This has an impact on the higher competition so it is possible to keep the unemployment rate high even though the percentage decreases every year.Unemployment, whatever the cause is always a concern of government as an indicator of success in the government (Miller and Williams, 1974; Dornbusch et al, 2008). So many ways must be taken to reduce the unemployment rate. Other data illustrates the number of registered workers and available job vacancies from 2000 - 2012.

The consequence of an increase in population will ultimately increase the number of labor force in need of work to generate income. The consequences must be met by providing employment for all the labor force. Based on Table 5 it can be seen that every year the number of jobseekers continues to increase. For that to be followed by increased employment opportunities.

The availability of employment opportunities is directly related to the increase in state revenues. Research conducted by Priyarsono and Kalangi (2008) found that if GDP increased by 1 percent alone, it would increase employment by 1.02 percent. The elasticity can be used to estimate the increased employment opportunities that might be created. Instead, Okun's law says that the unemployment rate will weigh on GDP by 2 percent due to decreased productivity (Dornbusch et al, 2008). Back to Table 5 below, employment fulfillment for both men and women still has not fulfilled job seekers' requests.

Table 5 Percentage of Employment Seekers, Jobs and Employment P1 acements Registered in Indonesia 2000 - 2012

\begin{tabular}{rrrrrrrrrr}
\hline \multirow{2}{*}{ Year } & \multicolumn{3}{c}{ Job seekers } & \multicolumn{3}{c}{ Job Vacancy } & \multicolumn{3}{c}{ Work Placement } \\
\cline { 2 - 10 } & \% Lk & \% Pr & \multicolumn{1}{c}{ Number } & \% Lk & \% Pr & Number & \% Lk * & \% Pr * & Number \\
\hline 2005 & 54.05 & 45.95 & 382,706 & 52.38 & 48.02 & 167,724 & 86.58 & 80.97 & 141,277 \\
2006 & 49.85 & 50.15 & 696,600 & 47.33 & 52.67 & 201,415 & 172.19 & 172.12 & 346,739 \\
2007 & 55.42 & 44.58 & 375,162 & 61.37 & 38.63 & 300,402 & 59.11 & 57.37 & 175,545 \\
2008 & 45.58 & 54.42 & $2,970,286$ & 49.15 & 50.85 & $2,360,377$ & 80.24 & 89.20 & $20,051,512$ \\
2009 & 54.93 & 45.07 & $4,707,875$ & 55.19 & 44.81 & $3,149,514$ & 61.92 & 64.68 & $1,989,153$ \\
2010 & 51.06 & 48.94 & $2,487,677$ & 42.02 & 57.98 & $1,197,832$ & 60.81 & 68.61 & 782,565 \\
2011 & 40.98 & 59.02 & 728,440 & 37.58 & 62.42 & 326,617 & 67.87 & 70.56 & 227,169 \\
2012 & 56.39 & 43.61 & $1,299,377$ & 38.26 & 61.74 & 628,603 & 56.26 & 59.43 & 365,947 \\
\hline
\end{tabular}

Description: * counted against the number of jobs with the number of job placements

Source: Sakernas (BPS), 2015

The impact of the lack of employment is unemployment as shown in Table 4. Unemployed labor force in Indonesia is not only men, but also women. The number is more dominated by women who are seen to have many shortcomings in terms of physical because they are considered weak. Efforts to support women gain employment in the formal economy, such as flexible gender parliamentary quota and working hours, but further efforts are needed to bridge the gap between the sexes, especially with regard to discrimination, the quality of work in the dominated sectors of women and the allowing maternity leave as seen in Table 6 below : 
Table 6 Open Unemployment Rate by Sex and Age Group in Indonesia 2009 - 2012

\begin{tabular}{ccccccccc}
\hline & \multicolumn{9}{c}{ Sex and Year } \\
\cline { 2 - 9 } Age group & \multicolumn{9}{c}{ Women } & \multicolumn{7}{c}{ Man } \\
\cline { 2 - 9 } & 2009 & 2010 & 2011 & 2012 & 2009 & 2010 & 2011 & 2012 \\
\cline { 2 - 9 } $15-19$ & 28.88 & 28.60 & 30.06 & 26.52 & 26.64 & 27.52 & 28.50 & 26.08 \\
$20-24$ & 19.31 & 17.82 & 15.49 & 15.48 & 18.56 & 17.19 & 13.67 & 15.08 \\
$25-29$ & 11.12 & 11.21 & 8.37 & 7.77 & 9.35 & 7.79 & 6.79 & 6.97 \\
$30-34$ & 6.43 & 6.87 & 5.32 & 5.33 & 4.89 & 3.81 & 3.18 & 3.52 \\
$35-39$ & 4.60 & 5.11 & 4.22 & 3.81 & 3.62 & 2.32 & 1.84 & 1.90 \\
$40-44$ & 3.60 & 4.00 & 3.65 & 3.04 & 3.12 & 1.90 & 2.01 & 1.88 \\
$45-49$ & 3.06 & 3.48 & 2.86 & 2.46 & 3.01 & 1.69 & 1.69 & 2.02 \\
$50-54$ & 2.27 & 3.09 & 2.46 & 2.74 & 2.76 & 1.56 & 2.29 & 2.40 \\
$55-59$ & 1.88 & 3.90 & 3.03 & 1.15 & 2.85 & 1.67 & 2.50 & 1.80 \\
$60-64$ & 0.79 & 5.68 & 4.06 & 0.47 & 0.90 & 1.43 & 3.24 & 0.65 \\
amount & 8.47 & 8.74 & 7.62 & 6.77 & 7,51 & 6.15 & 5.90 & 5.75 \\
\hline
\end{tabular}

Source: BPS and Sakernas, 2015

Viewed from various ages, it turns out that women are more unemployed than men. The highest open unemployment is at the age of 15 to 24 years (Table 6). At that age should be filled with school or college. But the inequality of development resulted in educational facilities not reaching remote areas so many residents in the golden age just idle and become housewives. Gender issues become important to be lifted because the potential of human resources is still very abundant but nothing is accommodating (limited employment).

Unlike men, women tend to have lower productive ages. Especially if it is past the age above 50 years where the physical condition decreases. The obligation to work for women is not absolute, but the era of globalization demands everyone to compete in the economy. Access of men and women to formal employment increases over time, but the outcome of formality differs by gender. For example, 57.9 per cent of women workers work in the informal economy, while only 50.9 per cent of male workers work in the informal economy (ILO 2015).

\section{Conclusion and Suggestion}

\subsection{Conclusion}

Based on the results of descriptive analysis of the transformation of development and its relation to employment and gender issues, it can be concluded that:

1. Development in Indonesia will continue to grow by applying gender equality and not discriminating between men and women in terms of education or employment

2. Gender issues can not be separated from the desire of the people to develop economically through improving the quality of self in order to contribute maximally in building Indonesia.

\subsection{Suggestion}

Some of the things that can be suggested through this paper include:

1. Improving the quality of human resources through education must take precedence in order to compete in the era of globalization and world free market.

2. Gender issues should be an evaluation material that development not only belongs to male society, but women also have the same duty and rights in developing Indonesia.

\section{References}

[1] Ali, Muhammad. 2009. The Role of Women in the Global Economy (Reflection on Gender Movement in Indonesia). Journal of Musawa, Vol.1 No. 2: 231242.

[2] Central Bureau of Statistics. 2014. Population of Indonesia by Province and Sex.

[3] Central Bureau of Statistics. 2013. Percentage of Job Seekers, Jobs and Employment Placement Registered in Indonesia Year 2000 - 2012

[4] Central Bureau of Statistics. 2013. Open Unemployment Rate by Sex and Age Group.

[5] Central Bureau of Statistics. 2014. Employment of Indonesia in Figures Year 2006 - 2013.

[6] Chand, Indira. 2015. World Bank Group Report: Big Progress, Though Still a Barrier, in Promoting Women's Economics in East Asia and the Pacific. The World Bank: Press Release.

[7] Dornbusch R, F Stanley, R Startz. 2008. Macroeconomics (English Edition). Jakarta: Global Education Media.

[8] Harahap, Rahmi PA. 2014. Analysis of the Influence of Gender Inequality on Economic Growth in Central Java Province. Semarang: Diponegoro University.

[9] Indonesia Investments. 2015. Indonesia's Gross Domestic Product. downloaded from: www.indonesiainvestments.com/id/keuangan/angka-ekonomimakro/produk-domestik-bruto-indonesia/item 253 . 
[10] Indonesia Investments. 2015. Sector Contributions in Indonesia's GDP. www.indonesiainvestments.com/id/keuangan/angka-ekonomimakro/produk-domestik-bruto-indonesia/item 253 .

[11] International Labor Organization. 2014. Social Trends and Employment. Asian Decent Work Decade. Jakarta. Oxon: Routledge.

[12] The Ministry of Women's Empowerment and Child Protection. 2013. Human Development Based on Gender.

[13] Lestari, Soetji. 2014. Women in the Nyumbang Tradition in Rural Java: Protetics of Village Monetization Dynamics [Dissertation]. Bogor: Bogor Agricultural University.

[14] Miller, RL and RM Williams. 1974. Unemployment and Inflation: The New Economics of Wageprice spiral. New York: West Publishing Co.

[15] Norton GW, J Alwang, WA Masters. 2010. Economics of Agricultural Development: World
Food Systems and Resource Use. New York: Routledge.

[16] Priyarsono, DS and Kalangi, L. 2008. The Impacts of Investments in Agriculture and Agroindustry Sectors on Unemployment Reduction in the book "From Agriculture to Industry (Analysis in the Perspective of Regional Economic Development)". Bogor: IPB Press.

[17] Randy, Salim. 2011. Indonesia Towards a Just and Gender Inclusive Development. The World Bank: Press Release.

[18] Saifuddin. $1997 . \quad$ Gender Movement in Indonesia. Yogyakarta: Student Literature.

[19] Tjaja, Ratna P. 2000. Working Women and Social Implications. Journal script. The State Ministry of Transmigration and Population. Jakarta. 